\title{
Biology of Aphthona nigriscutis (Coleoptera: Chrysomelidae) in the laboratory
}

\author{
JAN J. JACKSON \\ Northern Grain Insects Research Laboratory, USDA-ARS, 2923 Medary Avenue, Brookings, SD 57006
}

\begin{abstract}
:
The flea beetle Aphthona nigriscutis Foudras was introduced to Canada in 1983 and the United States in 1989 for the biological control of leafy spurge, Euphorbia esula L. Life history data for A. nigriscutis are described based on laboratory studies using insect populations from Barnes County, North Dakota, and Fallon County, Montana. Initial emergence of males and females from spring soil samples was synchronized, but complete emergence for males preceded that of females. For the Barnes County population, $\approx 80 \%$ of the adults were female. When adults were held as mated pairs at $25^{\circ} \mathrm{C}$ and a photoperiod of $14: 10$ (L:D) h, male longevity was longer than that of the female with a median longevity of 221 and 124 days, respectively. Oviposition started $\approx 10$ days after female emergence and proceeded at a rate of 4 eggs per day over an average oviposition period of 109 days. Oviposition averaged 537 eggs per female with a range of 103-1,157. Eggs from the Fallon County population started to hatch within 10 days after oviposition when eggs were held at $25^{\circ} \mathrm{C}$. Egg hatch averaged near $60 \%$ and occurred over a period of $\approx 8$ days. Life history data for A. nigriscutis were similar to other univoltine Aphthona spp., except $A$. nigriscutis had a female-biased sex ratio, greater male longevity, and higher female oviposition.
\end{abstract}

\section{Keywords:}

Aphthona nigriscutis, adult biology, leafy spurge.

\footnotetext{
${ }^{1}$ Received for publication 20 January 1997; accepted 20 March 1997. This article reports the results of research only. Mention of a proprietary product does not constitute an endorsement or a recommendation for its use by USDA.
} 


\section{Introduction}

The flea beetle Aphthona nigriscutis Foudras was introduced to Canada in 1983 and the United States in 1989 as a biological control agent for leafy spurge, Euphorbia esula L. (Rees et al. 1995). This noxious perennial weed infests $>1$ million hectares with significant infestations on the Great Plains of the United States and Prairie Provinces of Canada (Noble et al. 1979, Messersmith and Lym 1983). In pasture and rangeland, leafy spurge displaces desired forages, especially for grazing cattle. Cultural and chemical control methods can be effective but long-term suppression over large areas is often impractical and expensive.

Forty species of Aphthona have been reported to associate with spurges (Euphorbia sp.) in Europe and Asia (Harris et al. 1985, Pemberton and Wang 1989). Six species $[A$. abdominalis Duftschmid, A. cyparissiae Koch, A. czwalinae (Weise), A. flava Guillebeau, A. lacertosa Rosenhauer, and A. nigriscutis] have been established in the United States (Rees et al. 1995). For the univoltine species (i.e., all except $A$. abdominalis), adults usually emerge in June and July, feed on leaf tissues, and oviposit in the soil near the plant base. The 3 larval instars tunnel the root system (Maw 1981) causing damage to primary and lateral roots. These species overwinter as larvae, typically in the 3rd instar. Pupation occurs in the spring. Details of the life history have been described for $A$. $a b$ dominalis (Fornasari 1993), A. cyparissiae (Sommer and Maw 1982), and A. flava (Sommer and Maw 1982).

Maw (1981) compared the occurrence of A. cyparissiae, A. czwallinae, A. flava, A. lacertosa, and A. nigriscutis in several sites in Europe with different spurge species, vegetational characteristics, and soil texture. A. nigriscutis was similar to A. flava and $A$. cyparissiae in its frequent association with Euphorbia cyparissias (Maw 1981, Sommer and Maw 1982, Pemberton and Rees 1990). A. nigriscutis differed in that it favored dry habitats (Maw 1981). All 3 species have been widely distributed and established throughout the northern Great Plains for the biological control of leafy spurge (Rees et al. 1995). Detailed knowledge of the life history of A. nigriscutis would assist laboratory research and the effective use of this biological control agent in the field. This study reports on adult emergence, longevity, oviposition pattern, oviposition rate, and egg hatch under laboratory conditions.

\section{Materials and methods}

Aphthona nigriscutis for the emergence, longevity, and oviposition studies were collected in May (1994 and 1995) as late stage larvae and pupae in soil samples. The samples were collected from a 1989 release site established by Bob Carlson and Don Mundal (North Dakota State University, Fargo, ND) in Barnes County, North Dakota. Five undisturbed samples $(15 \mathrm{~cm}$ deep and $10.5 \mathrm{~cm}$ diameter) were placed into each of 2 plastic buckets. A bouquet of leafy spurge was changed 2-3 times per week to supplement shoots that grew from the soil samples. The soil was watered periodically. Buckets were covered with a fine screen and held at $25^{\circ} \mathrm{C}$ with a photoperiod of 14:10 (L:D) hours. Beetle emergence was checked daily.

Page 2 of 7 
Adults were sexed and paired within 24 hours of collection from the soil samples. Twenty and 19 male-female pairs were established in 1994 and 1995, respectively. Pairs were held in cages of clear acrylic tubing ( $7 \mathrm{~cm}$ long and $5 \mathrm{~cm}$ diameter) with a 44-mesh nylon screen cemented to one end. The open end of the tube was forced into sieved (particle diameter $<180 \mu \mathrm{m})$, moist soil held in the bottom of a petri dish (60 mm diameter by $15 \mathrm{~mm}$ deep). Narrow furrows were made in the soil to serve as oviposition sites. Cages were held at $25^{\circ} \mathrm{C}$, a photoperiod of 14:10 (L:D) hours, and 80\% RH. On Monday, Wednesday, and Friday, each pair was transferred to a new cage along with a fresh-cut stem tip (5-8 leaves) of leafy spurge. The stem tip rested on the moist soil in the bottom of the cage. Eggs were isolated from soil, leaf material, and cage surfaces by rinsing the cage and petri dish with water over a sieve (250- $\mu$ m openings). Eggs and debris were recovered on the screen and transferred to moist filter paper. Eggs were counted using a dissection microscope. Beetle mortality was recorded on the dates of transfer. Cages were maintained using the same methods until both individuals of the pair were dead. Data were checked for normality and summarized using SAS/Assist and Insight (SAS Institute 1991).

Aphthona nigriscutis adults used for the egg hatch study were collected in June 1994 from a 1990 release site established by Neal Spencer (Agricultural Research Service, Sidney, MT) in Fallon County, Montana. Approximately 1,000 beetles were placed in a screened, wooden framed cage $(30 \mathrm{~cm}$ wide by $30 \mathrm{~cm}$ deep by $60 \mathrm{~cm}$ long) with bouquets of fresh-cut leafy spurge. The cage was held at $25^{\circ} \mathrm{C}$, a photoperiod of 14:10 (L:D) hours, and 60\% RH. Leafy spurge bouquets were changed 3 times weekly. To facilitate egg collection, 2 petri dishes (150 $\mathrm{mm}$ diameter by $20 \mathrm{~mm}$ deep) were filled with sieved (particle diameter $<180 \mu \mathrm{m}$ ), moist soil and placed under the leafy spurge bouquets. The soil surface was scored with a knife to create 7-8 narrow furrows per dish. These dishes were changed weekly. After the colony was maintained for 1 month, a subsample of the weekly egg collection was acquired by offering the adults new dishes for a 24-hour period. The eggs from these new dishes were isolated from the soil as described previously, selected without bias (i.e., for size, color, or shape), and transferred with a fine wet brush to moist filter paper. Two or 3 groups of 100 eggs were transferred weekly for 5 consecutive weeks to moist filter paper and held in a covered petri dish at $25^{\circ} \mathrm{C}$ in darkness. Egg groups were checked daily for hatch until all eggs had hatched or perished. Regression analysis was conducted using SAS/Assist (SAS Institute 1991).

Leafy spurge used for adult food was collected from untreated natural infestations near the Northern Grain Insects Research Laboratory, Brookings, SD, or raised in the greenhouse (Lym 1992) with initial stem tip cuttings from a NGIRL infestation. Stem tips and bouquets used as food were from young shoots (i.e., $<30 \mathrm{~cm}$ long, before flowering).

\section{Results}

Adult emergence from the 1994 and 1995 soil samples held at $25^{\circ} \mathrm{C}$ was similar (Fig. 1). The 10 samples collected each year yielded 229 and 283 adults, respectively. Adult populations were $84 \%$ female in 1994 and $78 \%$ female in 1995. Both sexes emerged on the 1 st day of adult collection. During both years, female emergence extended over a 
longer time interval than male emergence. Male emergence was $80 \%$ complete after 13 days, whereas female emergence required $\approx 21$ days to reach $80 \%$.

\section{Total Adults}

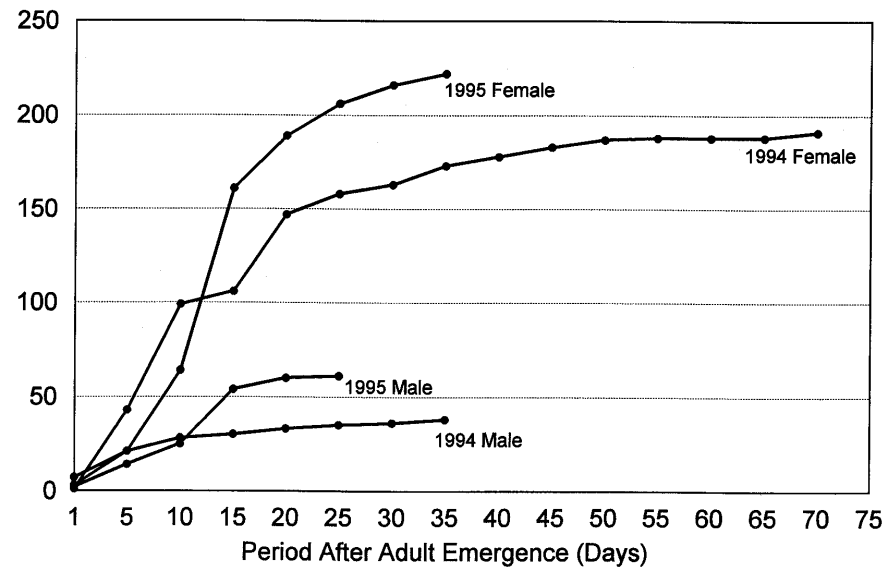

Fig. 1. Cumulative emergence of $A$. nigriscutis males and females from soil samples held at $25^{\circ} \mathrm{C}$ in 1994 and 1995.

Adult longevity distributions were not normal, except for 1994 males and 1995 females. Male longevity was more variable and the median longevity was longer as compared with the female (Table 1). When the 1994 and 1995 data were combined, median longevity for males was 221 days (range, 25-387) and for females was 124 days (range, 47-258). Sixty percent of the adults lived $>120$ days.

Table 1. Longevity (d) of $A$. nigriscutis adults.

\begin{tabular}{llcccc}
\hline Year & Sex & Median & $\begin{array}{c}25^{\text {th }} \\
\text { percentile }\end{array}$ & $\begin{array}{c}75^{\text {th }} \\
\text { percentile }\end{array}$ & $\begin{array}{c}\text { Percentile } \\
\text { difference }\end{array}$ \\
\hline 1994 & Male & 233 & 99 & 279 & 180 \\
1995 & Male & 174 & 83 & 245 & 162 \\
1994 and 1995 & Male & 221 & 96 & 259 & 163 \\
1994 & Female & 93 & 90 & 164 & 74 \\
1995 & Female & 162 & 111 & 191 & 80 \\
1994 and 1995 & Female & 124 & 90 & 191 & 101 \\
\hline
\end{tabular}

All pairs produced eggs. Females started ovipositing within 4-16 days after eclosion with a mean starting time of $10 \pm 3$ days. Initial oviposition was not significantly different for the 2 years $(F=0.1502 ; \mathrm{df}=1,37 ; P=0.7006)$. Mean oviposition per female was 
$537 \pm 262$ eggs (mean \pm SD) and was not significantly different for the 2 years $(F=$ $0.0167 ; \mathrm{df}=1,37 ; \mathrm{P}=0.8979)$. The range of female oviposition for both years was 103 1,157 . The period of oviposition from the 1 st to the last egg laid per female averaged 109 \pm 49 days and was not significantly different for the 2 years $(F=0.6337$; $\mathrm{df}=1,37 ; \mathrm{P}=$ 0.4311). The pattern of oviposition was similar for both years (Fig. 2) with $90 \%$ of the oviposition complete after $\approx 100$ days and the average number of eggs per day of female oviposition at $4 \pm 2$.

\section{Eggs Per Female}

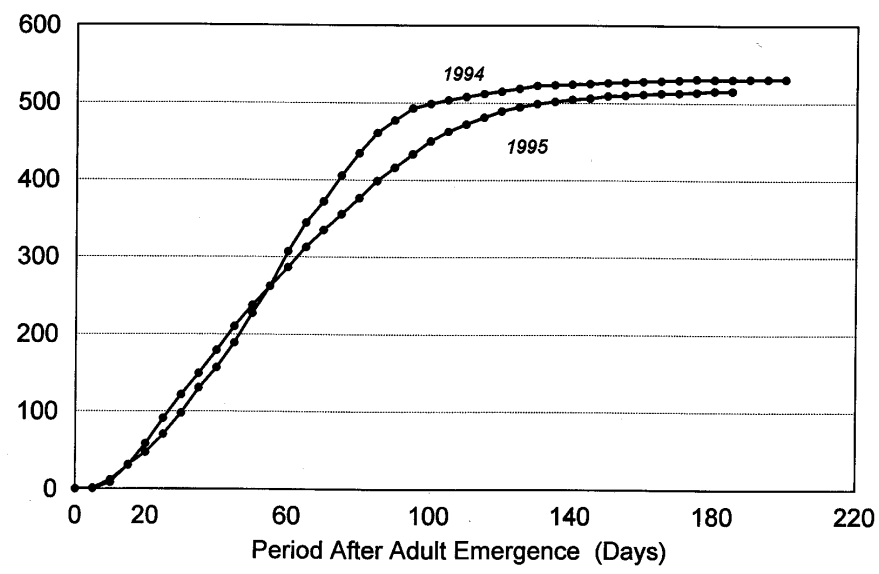

Fig. 2. Cumulative oviposition of $A$. nigriscutis females for $1994(n=20)$ and $1995(n=19)$.

Percentage of hatch from 1,100 eggs collected over 5 weeks from the Montana population of $A$. nigriscutis averaged $60 \pm 5 \%$ and did not significantly change over a 5-week period $(F=1.2127$; df $=1,9 ; P=0.2994)$. The average time to 1 st hatch for eggs held at $25^{\circ} \mathrm{C}$ was $10 \pm 1$ days. The average period of hatch was $8 \pm 2$ days. Although egg hatch was not routinely determined for A. nigriscutis from North Dakota, the hatch from 132 eggs collected over a 5-week period from 1 pair in 1995 averaged $68 \%$.

\section{Discussion}

Aphthona nigriscutis, A. cyparissiae, and A. flava are frequently associated with Euphorbia cyparissias in Europe including several sites in Hungary where these species are sympatric (Maw 1981). Life history data for A. cyparissiae and A. flava (Maw 1981, Sommer and Maw 1982, Pemberton and Rees 1990) were similar in many respects; with A. nigriscutis data from this study. This includes the synchrony of male and female eclosion, mating shortly after eclosion, 1 st oviposition at $\approx 1$ week after eclosion, a relatively 
uniform rate of oviposition over the major portion of the oviposition period, and a similar percentage for egg hatch.

Differences in the life history of A. nigriscutis, A. cyparissiae, and A. flava were observed with respect to the population sex ratio, adult longevity, and oviposition per female. Sommer and Maw (1982) and Fornasari (1996) reported a sex ratio near 1:1 for adult populations of $A$. abdominalis, $A$. chinchihi Chen, A cyparissiae, A. czwalinae, $A$. flava, A. seriata Chen, and $A$. venustula Kutschera. Adult populations of $A$. nigriscutis in Montana and Canada have been observed to be near 90\% female (Neal Spencer, personal communication) and a 1995 collection from Campbell County, South Dakota, was 97\% female (unpublished data). These observations are consistent with the collection of near 80\% females from the 1994 and 1995 North Dakota soil samples. Unequal sex ratios are not unusual for insect populations (Bedford 1980, Hoy 1985, Hamerski and Hall 1988) but if this contributes to a low mating frequency (e.g., $<45 \%$ of the females were mated in the 1995 Campbell County, South Dakota, population), population growth may be depressed. Additional samples and comparisons are needed from North American and European populations of $A$. nigriscutis before a female-biased sex ratio is considered typical for this Aphthona species.

Median adult longevity for $A$. nigriscutis was near 7 months for males and 4 months for females. In contrast, A. cyparissiae and A. flava adults maintained under laboratory and field conditions lived 3-4 months (Maw 1981). The longer longevity of $A$. nigriscutis, especially the males, may be a characteristic of the species however, more likely, it was a response to the favorable rearing conditions in this study. Adults were handled with great care and fresh leafy spurge leaves were always available from field or greenhouse grown plants. To support laboratory studies, additional data on adult longevity should be collected for A. nigriscutis from several populations. This is especially important because of the large variation in longevity values observed in this study. For field studies, adult longevity would rarely exceed 4.5 months in the northern Great Plains (i.e., adult eclosion in June to a killing frost by mid-October). If $A$. nigriscutis adult populations do not persist until a killing frost, factors that are reducing adult longevity should be evaluated. With oviposition uniformly distributed over 3-4 months, female longevity is critical to sustaining the insect population.

Mean oviposition for an $\mathrm{A}$. nigriscutis female held in the laboratory was 537 eggs, with $21 \%$ of the females laying $>800$ eggs. This mean is about double the mean oviposition reported for laboratory held females of A. cyparissiae and A. flava (Maw 1981) and 9 times that reported for A. abdominalis (Fornasari 1993). The A. cyparissiae and A. flava data were based on females that survived 3 months. This is similar to the mean oviposition period observed for A. nigriscutis (i.e., 109 days). Although additional data from other $A$. nigriscutis populations should be collected, the oviposition potential of $A$. nigriscutis appears to be about double that of $A$. cyparissiae and A. flava. 


\section{Acknowledgments}

I thank Robert Brown for exceptional technical assistance in handling the pairs of flea beetles; Bob Carlson and Don Mundal (North Dakota State University) and Neal Spencer (USDA-ARS, Sidney, MT) for insects and guidance; and Sharon Clay (South Dakota State University) and Neal Spencer for a critical review of the initial draft of the manuscript.

\section{References cited}

Bedford, G. O. 1980. Biology, ecology, and control of plam rhinoceros beetles. Annu. Rev. Entomol. 25:309-339.

Fornasari, L. 1993. Life history of the flea beetle, Aphthona abdominalis Duftschmid, on Euphorbia esula L. (leafy spurge) in Italy. Biol. Control 3:161-175.

Fornasari, L. 1996. Biology and ethology of Aphthona spp. (Coleoptera: Chrysomelidae, Alticinae) associated with Euphorbia spp. (Euphorbiaceae), pp. 293-313. In: P.H.A. Jolivet and M. L. Cox [eds.], Chrysomelidae biology, vol. 3. Academic, Amsterdam.

Hamerski, M. R., and R. W. Hall. 1988. Laboratory rearing of Tetrastichus gallerucae (Hymenoptera: Eulophidae), an egg parasitoid of the elm leaf beetle (Coleoptera: Chrysomelidae). J. Econ. Entomol. 81:1503-1505.

Harris, P., P. H. Dunn, D. Schroeder, and R. Vonmoos. 1985. Biological control of leafy spurge in North America. pp. 79-92. In: A. K. Watson [ed.], Leafy spurge. Weed Sci. Soc. Am. Mongr. 3.

Hoy, M. A. 1985. Recent advances in genetics and genetic improvement of the phytoseiidae. Annu. Rev. Entomol. 30:345-370.

Lym, R. G. 1992. Propagation of Euphorbia esula for leafy spurge biocontrol agents. Weed Sci. 40:326332.

Maw, E. 1981. Biology of some Aphthona spp. (Col.: Chrysomelidae) feeding on Euphorbia spp. (Euphorbiaceae), with special reference to leafy spurge (Euphorbia sp. near esula). M.S. thesis, University of Alberta, Edmonton, Canada.

Messersmith, C. G., and R. G. Lym. 1983. Distribution and economic impacts of leafy spurge in North Dakota. N.D. Farm Res. 40:8-13.

Noble, D. L., P. H. Dunn, and L. A. Andres. 1979. The leafy spurge problem, pp. 8-15. Proceedings, Leafy Spurge Symposium. Dakota Cooperative Extension Service, Fargo.

Pemberton, R. W., and N. E. Rees. 1990. Host specificity and establishment of Aphthona flava Guill. (Chrysomelidae), a biological control agent for leafy spurge (Euphorbia esula L.) in the United States. Proc. Entomol. Soc. Wash. 92:351-357.

Pemberton, R. W., and R. Wang. 1989. Survey for natural enemies of Euphorbia esula L. in northern China and Inner Mongolia. Chin. J. Biol. Control 5:64-67.

Rees, N. E., N. R. Spencer, L. V. Knutson, L. Fornasari, P. C. Quimby, Jr., R. W. Pemberton, and R. M. Nowierski. 1995. Leafy spurge Euphorbia esula (complex) Spurge family - Euphorbiaceae. In: N. E. Rees, E C. Quimby, Jr., G. L. Piper, E. M. Coombs, C. E. Turner, N. R. Spencer, and L. V. Knutson [eds.], Biological control of weeds in the West. Western Society of Weed Science, Bozeman, MT

SAS Institute. 1991. SAS/ASSIST, SAS/INSIGHT and SAS/STAT-REG. SAS Institute, Cary, NC.

Sommer G., and E. Maw. 1982. Aphthona cyparissiae (Koch) and A. flava Guill. (Coleoptera: Chrysomelidae): two candidates for the biological control of cypress and leafy spurge in North America, pp. 1-19. Commonwealth Institute of Biological Control, Delemont, Switzerland. 